\title{
DIVISÃO ESTRATIGRÁFICA DO MESOZOICO NO ESTADO DE SÃO PAULO
}

\author{
PAULO CÉSAR SOARES*
}

\begin{abstract}
The Mesozoic of the Paraná Basin in São Paulo State admits a division in four formations: Pirambbia, Botucatu, Serra Geral and Bauru.

The Piramboia Formation, as defined in this paper, exhibits a maximum thickness of more than $300 \mathrm{~m}$ in the central part of the State, reducing towards the Ponta Grossa arc (South) and towards the northeast basin boundary. This Formation is composed of various cycles, represented by channel deposits succeded by overbank deposits. It consists essencially of very fine to medium grained muddy sandstones with great textural uniformity and single mineralogical suite. These characteristics reflect great intensity of reworking of the material furnished to the basin.

The Botucatu Formation is constituted by sediments of desertic environments; very fine to fine grained eolian sandstones with good sorting, cross stratification of medium to great width; locally conglomeratic sandstones, deposited by wadis; and rarely muddy sandstones and mudstones, settled down on lakes. The Serra Geral Formation embodies basaltic flows and at the lower part intertongues with the Botucatu sandstones. The Bauru Formation is composed of fluvial sandstones and mudstones, and fluvio-lacustrine calcareous sandstones, with basal conglomerate, over an erosional unconformity sculptured on basalts, and, locally, sandstones.

The boundary of the Mesozoic and Paleozoic sequences in the São Paulo State is an unconformity sculptured on rocks of different ages. In the Rio Grande do Sul State, deposits correlated to the Pirambóia Formation are denominated Rosário do Sul Formation, which embodies the Santa Maria beds (Late Triassic). The upper part of the Botucatu Formation is contemporaneous to the Serra Geral basalts (late Jurassic-early Cretaceous). Thus, the age of the Piramboia Formation is Middle Triassic to Jurassic and of the Botucatu Formation is Jurassic.
\end{abstract}

INTRODUÇÃo Durante os trabalhos de mapeamento geológico sistemático no Estado de São Paulo, executados para a Petrobrás (Andrade e Soares, 1971), foi verificado que a seqüência mesozóica apresenta aspectos peculiares na região. A Formação Botucatu, conhecida em suas três fácies, aquosa, lacustre e eólica, foi dividida em dois distintos pacotes: o inferior, fluvial, para o qual foi usada a denominação Formação Pirambóia, e o superior, de ambiente desértico, para o qual foi mantida a denominação Formação Botucatu.

Posteriormente, realizamos uma análise estratigráfica regional dos arenitos Botucatu $\mathrm{e}$ Pirambóia, que constituem a seqüência final de sedimentação do Gondwana. Executamos o levantamento das seções e dos afloramentos mais representativos da seqüência, fizemos a análise das estruturas sedimentares dos arenitos, da textura e da mineralogia de mais de uma centena de amostras coletadas e analisamos perfis de poços da Petrobrás perfurados neste Estado (Soares, 1973). Paralelamente, fizemos uma pesquisa generalizada sobre a validade da extensão, para outras regiões, da divisão estratigráfica adotada para o centro-leste de São Paulo. Investigamos seções no Estado do Paraná, e no nordeste, sudoeste e parte central do Rio Grande do Sul.

Mais recentemente, realizamos o mapeamento geológico sistemático da faixa sedimentar no nordeste do Estado de São Paulo, em convênio com a Comissão Nacional de Energia Nuclear, estendendo-se para aí os conceitos aqui adotados de Formação Botucatu e Formação Pirambóia (Soares et al., 1973).

*Departamento de Geologia e Mineralogia da Faculdade de Filosofia, Ciências e Letras de Rio Claro, Rio Glaro, São Paulo 
No presente trabalho, incluímos o mapa geológico do Mesozóico no centro-leste de São Paulo. Constitui uma redução, com modificações e simplificações introduzidas, dos mapas apresentados à Petrobrás (Fig. 1). A presença do mapa tem por objetivo apenas facilitar a visualização da ocorrência das formações em seus novos conceitos aqui propostos e situar geograficamente os elementos da geologia da região que são mais frequỉentemente citados no texto.

A Formação Bauru, embora investigada e mapeada na regiăo, não foi objeto de estudo neste trabalho. Quanto aos basaltos da Formação Serra Geral e intrusivas contemporâneas, tratamos apenas das relações com as formações Botucatu e Pirambóia.

Neste trabalho, nosso principal objetivo é redefinir a Formação Botucatu, como sedimentos de ambiente desértico, e a Formação Pirambóia, como sedimentos de ambiente fluvial, e caracterizar as relações de contato entre estas unidades.

Divisăo estratigráfica A divisão estratigráfica da coluna mesozóica no Estado de São Paulo, em linha gerais, tem sido em três formações: Serra Geral, Botucatu e Bauru. O arenito Caiuá ocorre somente no extremo oeste junto ao vale do Rio Paraná e sua posição estratigráfica entre as formações Serra Geral e Bauru tem sido contestada por Bósio e Landim (1971), e Landim e Fulfaro (1972), que o consideram do Cenozóico.

$\mathrm{O}$ arenito Botucatu foi descrito pela primeira vez, em 1889, por Gonzaga de Campos (in Salamuni e Bigarella, 1967). Este nome, emprestado da Serra de Botucatu, foi usado para designar arenitos com estratificação cruzada de grande porte, sotopostos ou intercalados a derrames basálticos. O conteúdo da designação era estritamente litológico, não estratigráfico.

Os geólogos da Comissão Geográfica e Geológica do Estado de São Paulo conheciam a ocorrência de camadas de siltitos e argilitos bem como arenitos argilosos, às vezes maciços, nas proximidades de Pirambóia, às quais chamavam camadas Pirambóia. Alguns autores consideraram distintamente o "arenito Botucatu" e o "arenito Pirambóia", como sugere a legenda do mapa geológico do Estado de São Paulo da Comíssão Geográfica e Geológica, de 1929. Outros, entretanto, consideraram o Pirambóia como camadas intercaladas dentro do Botucatu, levando Washburne, em 1930. em sua monografia sobre o petróleo no Estado de São Paulo, a designar Arenito Botucatu stricto sensu para o pacote superior de arenitos eólicos e Arenito Pirambóia para o pacote inferior de arenitos fluviais. Deve-se a Washburne (1930) uma das melhores caracterizações destes pacotes. Lamentavelmente Pacheco, numa tradução da obra de Washburne (1936), propôs que fosse abandonada a designação Pirambóia após uma crítica ao autor da obra por uso inadequado do termo.

Entretanto, em 1947, o novo mapa geológico do Estado de São Paulo apresentava, na legenda, as referências Arenito Botucatu e Arenito Pirambóia como unidades distintas, embora não representadas separadamente.

Almeida e Barbosa (1953) aceitaram em parte os conceitos de Washburne, porém atribuem uma espessura "senão de uns poucos metros" ao arenito Pirambóia. Segundo estes autores, "a série São Bento pode ser dividida, à base de diversidade geológica, num membro inferior, o arenito Pirambóia, com caráter predominantemente fluvial, seguido de outras fácies mais elevadas alternadas, de arenito élico Botucatu, intercalando muito localmente uma fácies lacustre (Santana) e derrames basálticos correlacionáveis às chamadas 'eruptivas da Serra Geral' da seção clássica catarinense".

Apesar da inexistência de uma caracterização estratigráfica adequada deste pacote de arenitos mesozóicos, Sandford e Lange (1960) consideraram o Pirambóia e o Botucatu como formações. Outros trabalhos mais recentes (Mendes, 1961; Salamuni e Bigarella, 1967; Paraguassu, 1968; Fulfaro e Bósio, 1968), embora acentuassem uma mais signifi- 


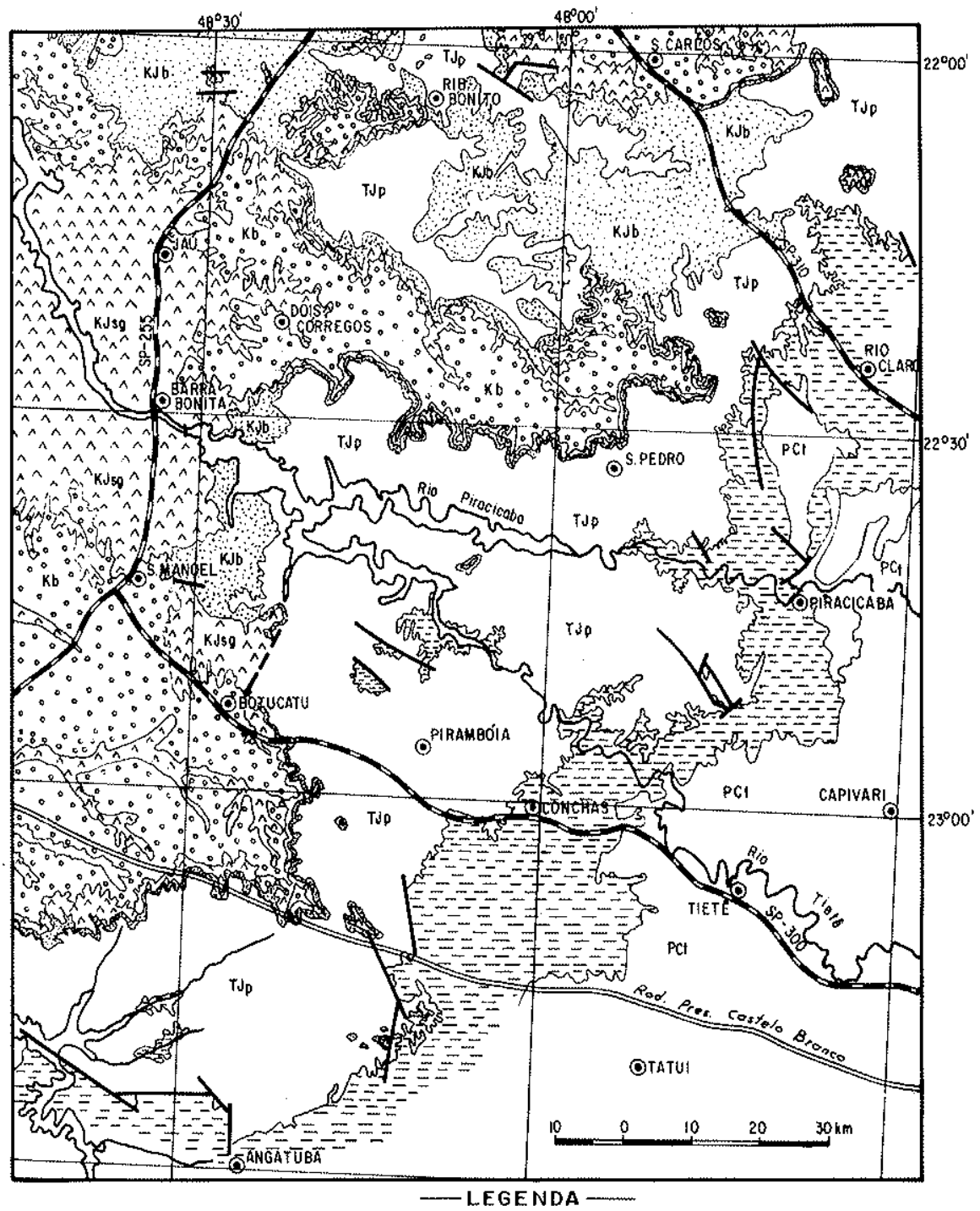

Obs.:- As rochas intrusivos não estõo representodos no mapa.
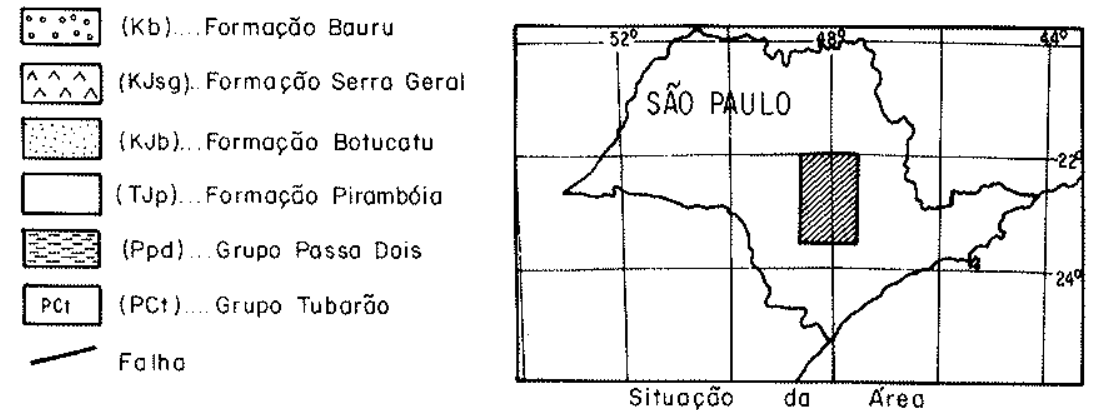

Figura 1 - Mapa geológico simplificado do centro-leste do Estado de São Paulo (modificado de Andrade e Soares, 1971) 
cativa ocorrência dos sedimentos fluviais, usaram outras qualificações, como fácies ou litótopo para Pirambóia e Santana, ou mesmo abandonaram tais designações. A designação Formação Botucatu tem ainda sido usada para incluir toda a seção mesozóica pré-vulcânica.

Mendes (1971), numa avaliação dos progressos do conhecimento da estratigrafia da bacia do Paraná, lembra recentes pesquisas que demonstram ser dominantes as fácies subaquosas na Formação Botucatu ao menos nos dois terços inferiores de sua espessura, considerando desprovidos de sentido os nomes Pirambóia e Santana.

Recentemente, caracterizamos sucintamente o pacote de arenitos fluviais da seção mesozóica sotopostos aos arenitos é́licos, concluindo pela conveniência de se usar a designação Formação Pirambóia para o mesmo (Soares, 1972a). Isto porque, independentemente da deficiente caracterização deste pacote e da diversidade de conceitos envolvidos na denominação Pirambóia, esta esteve sempre associada a camadas sedimentares de origem subaquosa.

Enumeramos a seguir as principais informações que temos obtido em nossos trabalhos na região a respeito da seqüência mesozóica pré-vulcânica:

1. Ocorre em todo o centro-leste de São Paulo, sobre uma discordância esculpida no Permiano, um pacote de arenitos de granulação variável, dominantemente muito fina a média, muito a pouco silto-argilosos, exibindo estratificação cruzada planar e acanalada e plano-paralela, com variação cíclica de litologia na vertical, intercalando camadas de lamitos arenosos e apresentando, em superfície, cores variáveis, em tons claros de amarelo, roxo, vermelho e verde.

2. Sobrepõem-se a este pacote arenitos de granulação fina a muito fina dominante, com estratificação cruzada planar tangencial de médio a grande porte, friáveis. perior

3. O pacote inferior mantém espessura duas ou mais vezes maior que o pacote su-

4. O contato entre os dois pacotes é uma superficie de brusca mudança textural, estrutural e de cor, em algumas áreas, enquanto em outras áreas é uma zona de poucos metros com modificação gradual dessas características. Este contato foi mapeado sem maiores dificuldades na escala 1:50000, no centro-leste (Fig. 1) e nordeste do Estado de São Paulo.

Dadas essas características sucintas, passamos a usar Formação Pirambóia para o pacote inferior e Formação Botucatu, para o superior. Adiante redefiniremos adequadamente estas duas unidades (Figs. 2 e 3 ).

Os depósitos de canais da Formação Pirambóia, com estratificação cruzada bem desenvolvida, em calha ou planar, tangencial na base, são muito similares aos eólicos da Formação Botucatu. Esta semelhança é atribuível à similaridade dos dois processos de sedimentação; no fluvial, além de deposição em barras, desenvolvem-se dunas ou ondas de areia, subaquosas, com geometria e movimento das areias similares aos de dunas élicas (Harms e Fahnestock, 1965). As diferenças na seleção, devidas à diferente fluidez do meio aquoso e eólico (Tabs. I e II), e as associações litológicas e de estruturas sedimentares permitem distinguir os sedimentos de rios meandrantes (de canais e de transbordamento) da Formação Pirambóia dos de ambiente desértico (torrenciais lacustres e eólicos) da Formação Botucatu (Soares, 1973). Foge ao escopo deste trabalho apresentar a caracterização faciológica de cada subambiente dessas unidades, o que será feito posteriormente.

Almeida (1953) restringiu o uso da Formação Botucatu aos arenitos eblicos, porém considerou éblicos alguns corpos de arenito de canais fluviais como pode ser deduzido pela espessura atribuída ao Botucatu e pela descrição de alguns afloramentos. A ocorrência- 


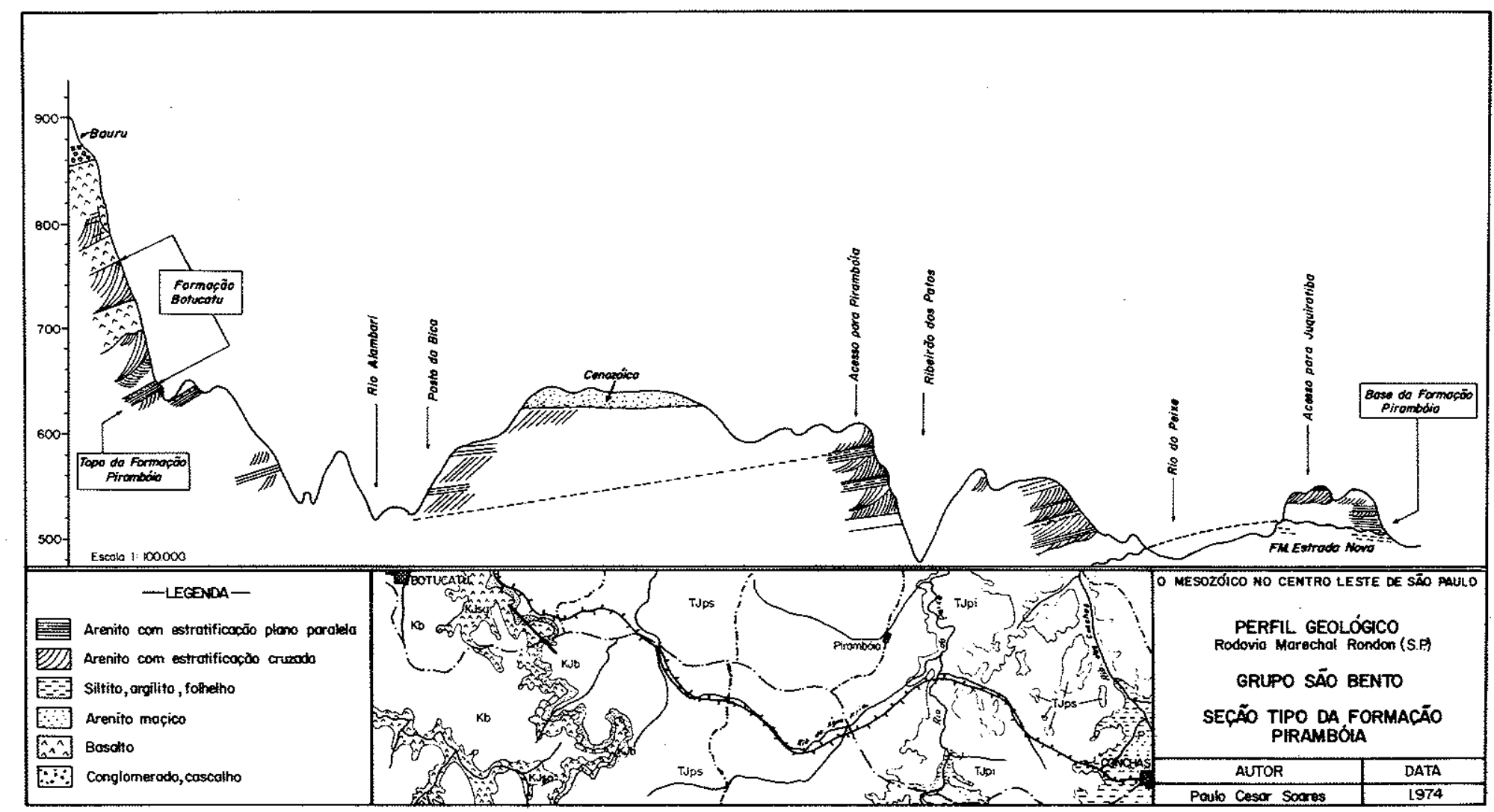

Figura 2 - Perfil geológico, Rodovia Marechal Rondon (SP), Grupo São Bento, seção-tipo da Formação Pirambóia 
-tipo da fácies Santana deste autor corresponde a depósitos de baixios de planície de inundação que sucede de forma cíclica os depósitos de canais da Formação Pirambóia, encontrados em vários níveis desta unidade (Fig. 3). Depósitos lacustres bem como de rios temporários são encontrados na Formação Botucatu (Soares, 1973), tendo sido descrito por Almeida (op. cit.) na Serra de Rifaina (SP) e da Esperança (PR), respectivamente.

A Formação Botucatu ocorre abaixo e intercalada nos primeiros derrames basálticos. Em certos locais há mesmo interdigitamento entre os arenitos e os basaltos. Tal dificuldade em caracterizar este contato levou alguns autores a considerarem mais apropriado o uso do termo Botucatu para designar os arenitos e os magmatitos (Mendes e Fulfaro, 1968; Cordani e Vandoros, 1967). É desejável entretanto uma precisão maior nas designaçóes estratigráficas do Mesozóico. As dúvidas que surgem na base da Formação Serra Geral, entendida em seu conceito original de basaltos formados por derrames intercalando corpos de arenito, devem ter uma interpretação local com critérios definidos regionalmente devido a dois principais fatos: $1 .^{\circ}$ ) este contato não constitui uma superficie contínua; e $2 .^{\circ}$ ) é dificil definir se estamos em presença de magmatitos extrusivos ou intrusivos. Por outro lado, é aconselhável excluir da Formação Serra Geral pequenos corpos basálticos sotopostos a maiores espessuras de arenitos. Regionalmente, e em termos de bacia, esta questão pode parecer superflua, porém em mapeamentos de detalhe o procedimento sugerido evita que se cometam inversões na coluna.

A divisão estratigráfica para o Mesozóico que aqui propomos está no Quadro I, abaixo.

\begin{tabular}{llll}
\hline GRUPO & FORMAÇÃO & CONTATO & \multicolumn{1}{c}{ LITOLOGIAS } \\
\hline & Bauru & Discordância erosiva & $\begin{array}{l}\text { Arenitos, conglomerados, } \\
\text { calcários, conglomerado basal }\end{array}$ \\
\hline & $\begin{array}{l}\text { Serra } \\
\text { Geral }\end{array}$ & Interdigitamento & $\begin{array}{l}\text { Basaltos, subsidiariamente } \\
\text { arenitos }\end{array}$ \\
\cline { 2 - 4 } $\begin{array}{l}\text { São } \\
\text { Bento }\end{array}$ & Botucatu & Diastemas & $\begin{array}{l}\text { Arenitos, raramente } \\
\text { conglomerado e lamitos }\end{array}$ \\
\cline { 2 - 4 } & Pirambóia & $\begin{array}{l}\text { Arenitos, siltitos, folhelhos } \\
\text { (ambiente fluvial) }\end{array}$ \\
& & Discordância erosiva & Regolito fóssil \\
\hline
\end{tabular}

Esta classificação visa separar em unidades diferentes aqueles depósitos realizados em ambientes diferentes, facilitando uma busca de camadas correlatas em outras partes da Bacia do Paraná.

É hábito dos geólogos brasileiros, nas questões de estratigrafia, seguirem as normas. do Código de Nomenclatura Estratigráfica da American Comission on Stratigraphic Nomenclature (1963).

$\mathrm{Na}$ classificação que propomos, deixamos de observar as recomendações dos artigos $9 \mathrm{c}$ e $14 \mathrm{~b}$, ou seja: ao se dividir uma formação em duas outras não deve ser usado o nome daquela para qualquer destas. Assim sendo, a designação Botucatu deveria ser abandonada e proposto outro nome para o pacote de arenitos eólicos. Como o objetivo do Código é simplificar, consideramos mais recomendável fugir a estas normas que abandonar um nome cujo uso foi consagrado na literatura geológica, cujo conceito genético esteve quase sempre associado a arenitos eólicos, e não foi modificado aqui.

$\mathrm{O}$ uso da designação Botucatu, incluindo espesso pacote de arenitos fluviais, decorreu mais freqüentemente de uma interpretação incorreta da gênese desses sedimentos. $O$ 


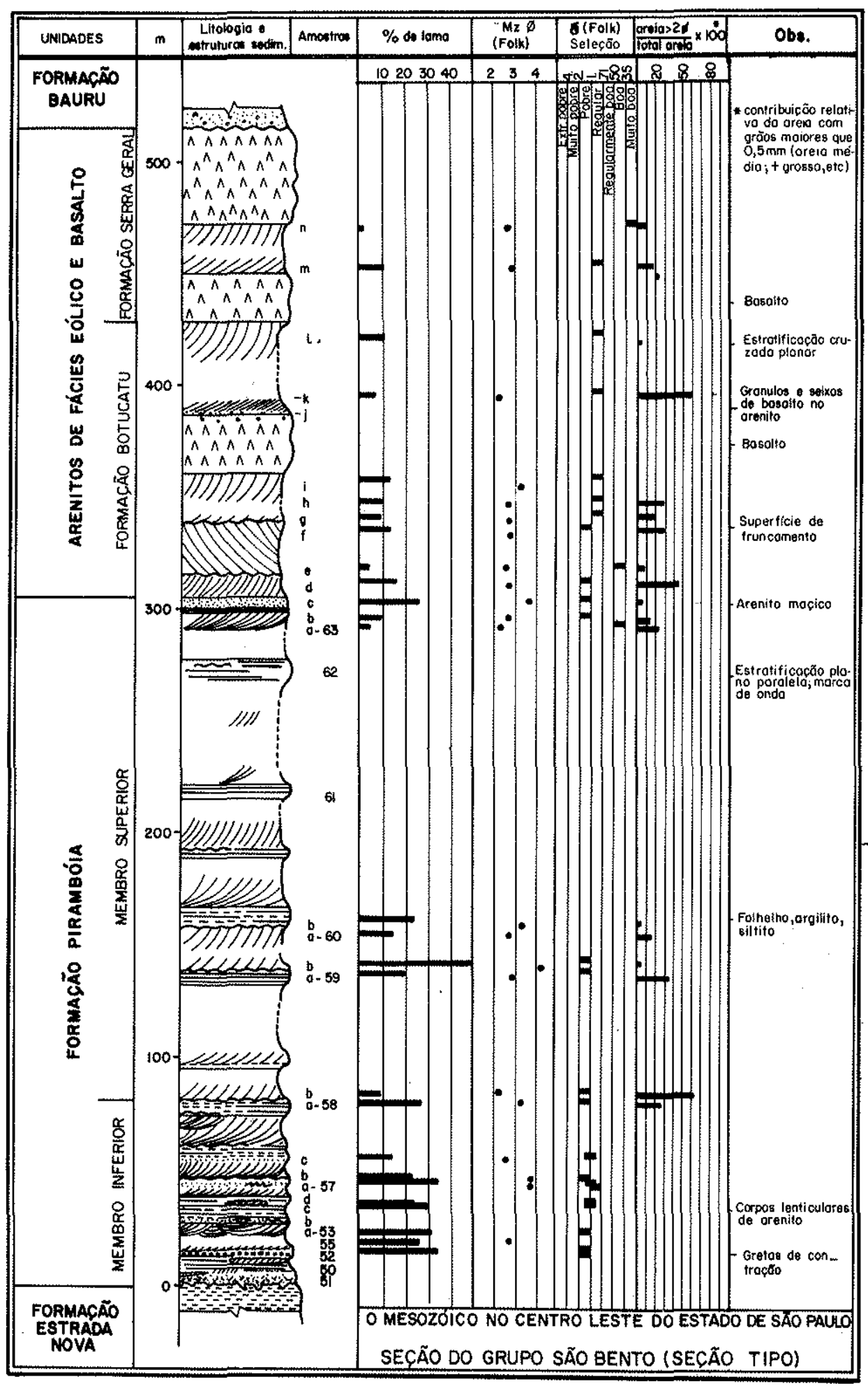

Figura 3 - Seção do grupo São Bento (seção-tipo) 
conteúdo estratigráfico de arenitos Botucatu, como pacote de arenitos eólicos, e Pirambobia, como pacote de sedimentos aquosos é aqui retomado com as redefiniç̃es necessárias.

Propomos ainda que nos casos de possível confusão terminológica seja usada a designação Botucatu stricto sensu com o significado que neste trabalho se dá para Botucatu.

a. FORMAÇÃO PIRAMBÓIA 1. Definiģão $e$ ocorrência A Formação Pirambóia é uma das unidades sedimentares de maior ocorrência no centromleste de São Paulo. Sua faixa de afloramento estende-se desde a divisa com Minas Gerais até o Paraná, manten. do-se com largura variável. Na bacia do Rio Piracicaba sua largura ultrapassa $50 \mathrm{~km}$, diminuindo para $5 \mathrm{~km}$ em Ipeúna-Serra de Itaqueri e Morro do Bofete-Torre de Pedra (Fig. 1).

As feições morfológicas mais características da área de ocorrência da Formação Pirambóia são as encostas escalonadas e os extensos areais existentes sobre as colinas tabuliformes. Excetua-se a parte inferior desta unidade, caracterizada por pequenas colinas com encostas côncavomconvexas, onde o solo desenvolvido permite utilização agrícola. Estas feições permitiram-nos distinguir duas unidades dentro da Formação Pirambóia que chamaremos aqui, informalmente, membro inferior e membro superior, com diferenças sutis nas características texturais e estruturais (Fig. 3).

$\mathrm{O}$ membro inferior aparece mais diferenciado do superior entre Ipeúna e Bofete, até onde foi separado. Sua fácies é mais argilosa, predominam estratificação plano-paralela e cruzada acanalada de pequeno porte, como pode ser visto de Artemis para Pau-d'Alho ou para Águas de São Pedro. São freqüentes as camadas de argila, folhelhos arenosos e sílticos. Sua ocorrência parece estender-se até Fartura (Andrade, comunicação pessoal).

O membro superior é caracterizado pela disposição dos bancos de arenitos, pouco a muito argilosos, com estratificação cruzada planar tangencial de médio a pequeno porte, sucedidos por bancos de arenitos muito argilosos, com estratificação plano-paralela, la-

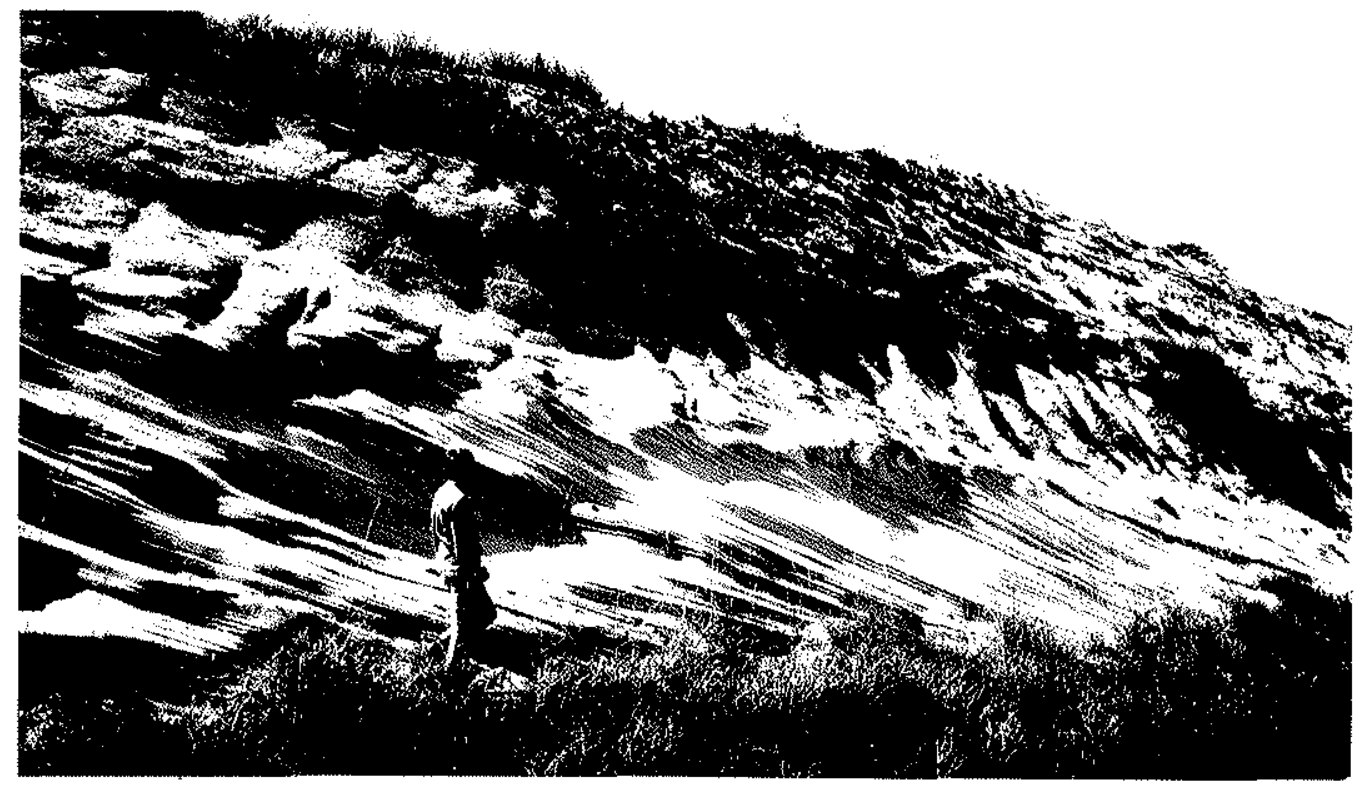

Foto 1 - Pacote de arenitos com estratificação cruzada planar, tangencial na base, sucedido por pacote com acamamento plano-paralelo (Rodovia Castelo Branco, SP, km 172) 
mitos e argilitos arenosos, numa clara repetição cíclica (Foto 1). O teor em lama (silte + + argila) é bastante variável, com uma média em torno de $20 \%$. A granulação é homogênea, variando entre muito fina e média, dominando as areias finas e seleção pobre. A melhor exposição deste membro é no novo ramal da Ferrovia Paulista S.A. (Fepasa) entre Rio Claro e Itirapina. Nas proximidades de Pirambóia são raros os cortes que dão uma visão de conjunto da Formação Pirambóia, embora sua expressão morfológica esteja aí bem evidenciada. A montagem de uma seção representativa desta unidade na área que lhe empresta o nome, ou seja, na área-tipo, foi feita ao longo da Rodovia Marechal Rondon, entre Conchas e a Serra de Botucatu (Figs. 2 e 3). Algumas propriedades texturais são apresentadas na Tab. 1.

Tabela I - Valores médios de algumas propriedades texturais dos arenitos da Formação Pirambóia, por regiões

\begin{tabular}{|c|c|c|c|c|c|}
\hline PARÂMETROS & S.P $-N E$ & S.P $-W L$ & S.P. - CB-MR & S.P-SUL & PR \\
\hline $\begin{array}{c}\text { So (Seleção) } \\
\text { (Frask) }\end{array}$ & 0,66 & 0,63 & 0,60 & 0,73 & 0,53 \\
\hline $\begin{array}{c}\sigma \emptyset \text { (Desvio) } \\
(\text { Inman })\end{array}$ & 0,96 & 1,24 & 1,30 & 0,66 & 1,50 \\
\hline $\begin{array}{c}a_{\emptyset} \\
(\text { Inmon })\end{array}$ & 0,27 & 0,40 & 0,43 & 0,03 & 0,46 \\
\hline $\begin{array}{c}\text { Mz (tamanho médio) } \\
\text { (Folk) }\end{array}$ & 2,74 & 3,38 & 3,13 & 1,49 & 3,00 \\
\hline $\begin{array}{c}\sigma_{1}^{\prime} \text { (Desvio padröa } \\
\text { (Folk) }\end{array}$ & 1,11 & 1,23 & 1,48 & 0,89 & 1,49 \\
\hline $\begin{array}{c}\% \text { lama } \\
\text { (Silte + argila) }\end{array}$ & 17,6 & 20,4 & 25,7 & 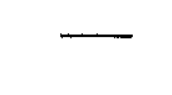 & 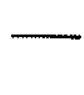 \\
\hline
\end{tabular}

S.P. -NE: nordeste do Estado de São Paulo ( 10 amostras)

S.P.-WL: centro leste do Estado de Säo Poulo, rodovio Washington Luiz e proximidades (4l amostras)

S.P.-CB-MR: centro leste do Estado de São Paulo, rodovio Castelo Branco e Marechal Rondon ( 38 amostras)

S.R SUL: região sul do Estado de São Paulo (Fartura), (6amostras) PR: Paranó-BR-277-Serra do Esperança (4 amostras)

A espessura da Formação Pirambóia tem seu máximo em torno de $300 \mathrm{~m}$ na Bacia do Tietê. Reduz-se para sul e para nordeste do Estado, atingindo $150 \mathrm{~m}$ em Analândia, $60 \mathrm{~m}$ em Franca até desaparecer pouco ao sul do Rio Grande.

Examinamos a seção mesozóica nos Estados do Paraná e do Rio Grande do Sul objetivando verificar a extensão da Formação Pirambóia para sul e comparar suas características. 
No Paraná há uma exposição da parte superior desta formação na BR-277, Rodovia Ponta Grossa-Foz do Iguaçu, na Serra da Boa Esperança (Fig. 4). Os arenitos são similares aos do Estado de São Paulo, tanto na granulometria como em estruturas sedimentares. Está exposto aí um ciclo fluvial completo. A espessura é relativamente pequena não devendo atingir mais de $40 \mathrm{~m}$.

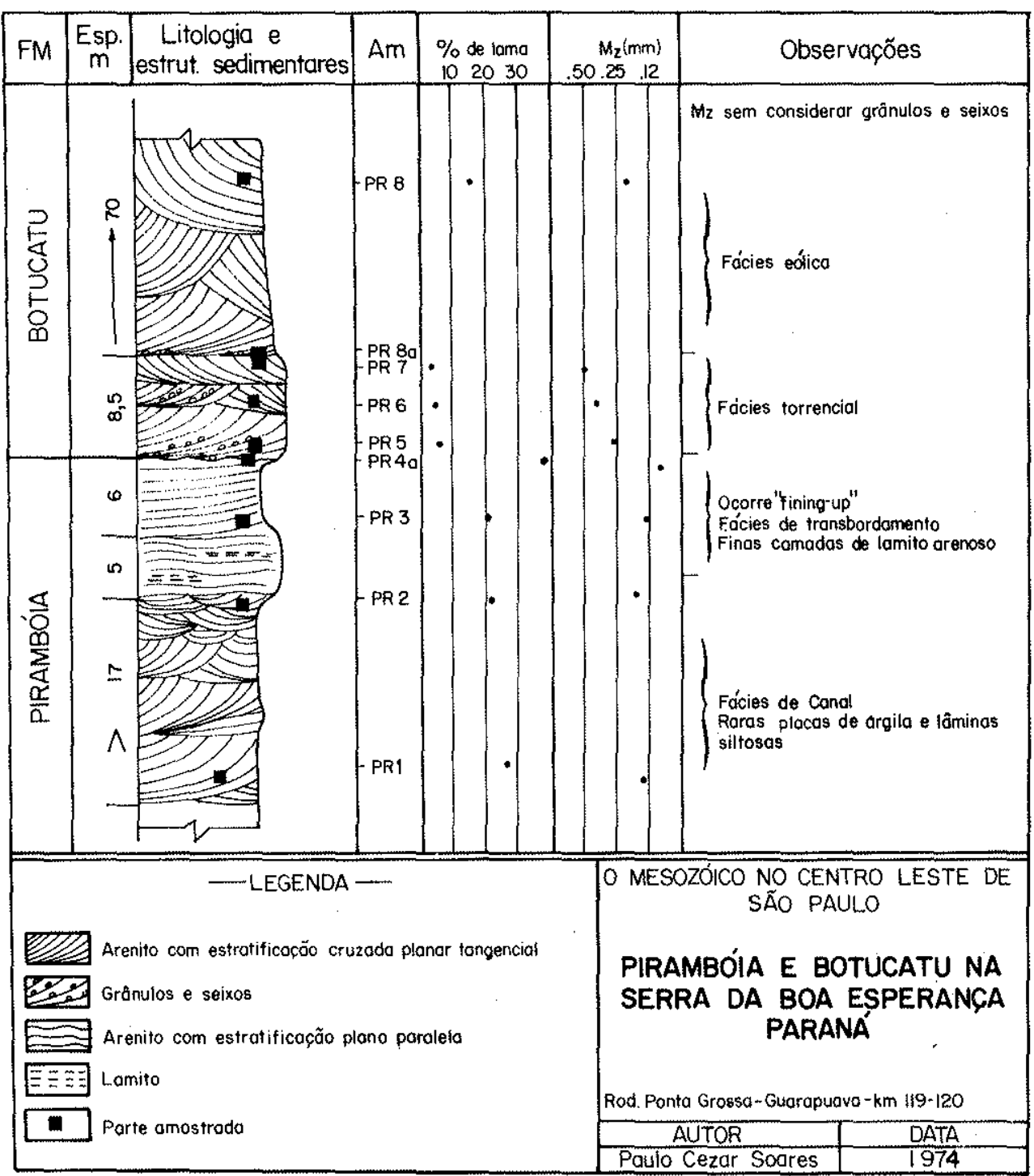

Figura 4 - Pirambóia e Botucatu na Serra da Boa Esperança (PR). Rodovia Ponta Grossa--Guarapuava, $\mathrm{km}$ 119-120

O contato basal da Formação Pirambóia está coberto por tálus. Este contato se faz com a Formação Rio do Rasto (Membro Morro Pelado). O contato superior é uma superfície de brusca mudança litológica (Foto 2). Sobre arenitos muito finos e com laminação plano-paralela da Formação Pirambóia ocorrem arenitos conglomeráticos com estratificação cruzada da fácies torrencial da Formação Botucatu. 


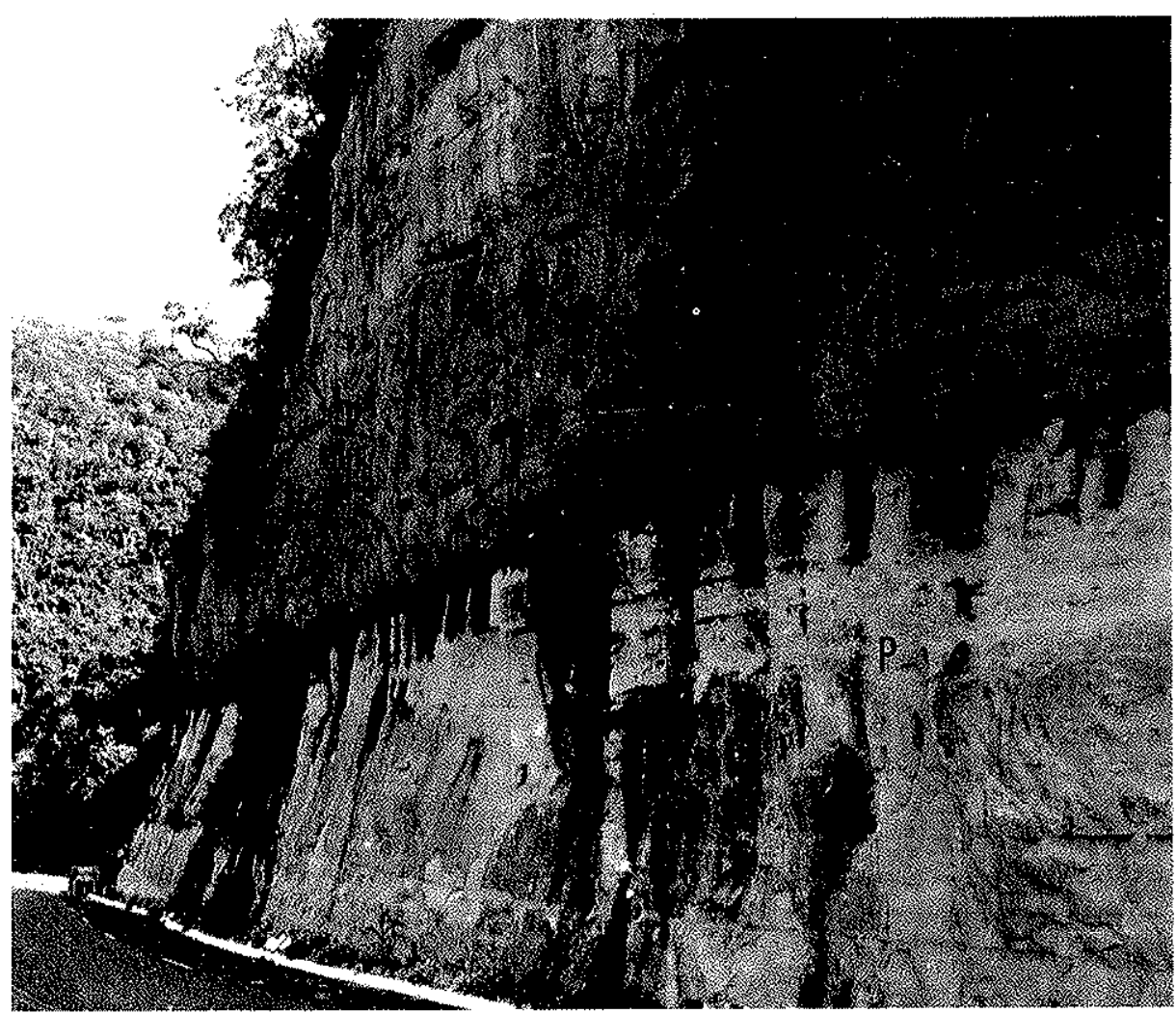

Foto 2 - Arenitos conglomeráticos (fácies torrencial, reg) da Formação Botucatu (B) sobre arenitos finos, acamamento plano-paralelo da Formação Pirambóia (P) (Rodovia Ponta Grossa - Guarapuava, Serra da Esperança, .PR.)

No Estado do Rio Grande do Sul, a seqüência mesozbica apresenta-se mais complexa, tendo sido objeto de estudos detalhados por Gamermann (1972) e Bortoluzzi (1974). Gamermann (op. cit.) englobou depósitos lacustres e fluviais das "formações" Rio Pardo, Santa Maria e parte do Botucatu numa única unidade que designou de Formação Rosário do Sul. Gamermann não conseguiu definir precisamente os contatos inferior e superior desta formação, considerando-os como gradacionais.

A Formação Rosário do Sul, no sudoeste (área da seção tipo) e no nordeste đo Rio Grande do Sul, apresenta as mesmas características estruturais e texturais que a Formação Pirambóia no Estado de São Paulo. As relações de contato naquelas duas regióes também nos pareceram idênticas às deste Estado.

Algumas seçôes que examinamos mais detalhadamente nos municípios de Gravataí e Taquara, na BR-290, São Sepé--Rosário do Sul-Livramento, revelaram a mesma situação estratigráfica que no Estado de São Paulo:

1. O pacote de arenitos, correlatos à Formação Pirambóia, denominados Formação Rosário do Sul, apresenta as mesmas características de granulação, o mesmo caráter cíclico com repetição na vertical das fácies de canal e transbordamento.

2. O contato basal deste pacote se faz com siltitos vermelhos, que intercalam finas camadas de arenito e sílex, pertencentes à Formação Estrada Nova, com fácies tipo Co- 
rumbataí, estando ausente a Formação Rio do Rasto. Recentemente, Figueiredo (1972) discutiu este contato, concluindo pelo caráter discordante.

3. O contato superior da Formação Rosário do Sul se faz com arenitos eólicos da Formação Botucatu (s.s.) de forma gradacional (Gamermann, 1972). Entretanto, em alguns locais são encontrados diastemas, com a presença de concentração de seixos na base do Botucatu.

Na parte central do Rio Grande do Sul, onde ocorre a "Formação" Santa Maria, existe maior complexidade estratigráfica. Gamermann (1972) considerou a "Formação" Santa Maria como uma fácies ocorrendo em níveis diferentes da Formação Rosário do Sul. Mais recentemente, Bortoluzzi (1974) propõe modificações na coluna da região. Num estudo minucioso sobre as relações estratigráficas da Formação Santa Maria, este autor propõe que seja designado Formação Rosário do Sul apenas o pacote de arenitos fluviais sotopostos às camadas Santa Maria; que para estas seja mantida a designação de Formação Santa Maria; que para os pacotes, fluvial e eólico, entre o Santa Maria e o Serra Geral, use-se Formação Botucatu.

Com o objetivo de confrontar a situação estratigráfica desta região central do Rio Grande do Sul com a de São Paulo, estendemos também nossas investigações às rodovias Pântano Grande-Santa Cruz do Sul e arredores desta cidade, Santa Maria-Candelária - Santa Cruz, São Sepé--Santa Maria e arredores desta.

Sob os aspectos que mais nos interessam, nossas conclusões podem ser assim resumidas:

1. Julgamos mais conveniente manter a designação Formação Rosário do Sul para todo o ciclo fluvial, no qual se intercala regionalmente uma ou mais fase flúvio-lacustre (fácies Santa Maria) e Formação Botucatu para o ciclo de ambiente desértico, como foi proposto por Gamermann (1972).

2. Apenas para efeitos descritivos, consideraremos Rosário do Sul no sentido de Gamermann e o dividimos em três partes:

- Na parte inferior, sotoposta às ocorrências da fácies Santa Maria, apresenta arenitos conglomeráticos, freqüentemente submaturos e imaturos nos depósitos de canal; nos depósitos de transbordamento os arenitos são finos, lamíticos, com acamamento plano paralelo, raros corpos acanalados com estratificação cruzada e camadas de lamitos vermelhos. Em alguns afloramentos lembra o membro inferior do Pirambóia; em outros, apresenta ciclos fluviais completos, como o membro superior (por exemplo: $\mathrm{km} 20 \mathrm{da}$ rodovia Pântano Grande-Rio Pardo).

- A parte média engloba as ocorrências da fácies Santa Maria; constitui-se essencialmente de lamitos avermelhados, arenosos, mais comumente maciços, subsidiariamente arenitos com concreções. Contém fauna fóssil do Triássico Superior (Bortoluzzi, 1974). $\mathrm{Na}$ base, em Santa Cruz do Sul, ocorre um lamito conglomerático, tipo diamictito, com $2 \mathrm{~m}$ de espessura. A espessura desta parte atinge até $50 \mathrm{~m}$, aproximadamente.

- A parte superior é formada por arenitos de granulação fina a muito fina (dominante), silto-argilosos, com estratificação plano-paralela ou cruzada, ou maciços. São raras e finas as camadas de lamitos. A ocorrência desta parte parece restrita para oeste de Candelária. Sua espessura é superior a $30 \mathrm{~m}$ nos arredores de Santa Maria. Seu contato com a fácies Santa Maria (parte média) é uma superficie de truncamento irregular das camadas lamíticas sotopostas, como na base de canais. $O$ contato com os arenitos eólicos da Formação Botucatu pode apresentar uma camada de aproximadamente $2 \mathrm{~m}$ de arenito conglomerático sobre a qual ocorre uma concentração de seixos, como na estrada de Camobi para Silveira Martins, a $16 \mathrm{~km}$ da primeira; constitui um pavimento rudáceo do deserto Botucatu. 
3. As formações Rosário do Sul e Pirambóia constituem ciclos geneticamente similares com as mesmas relações estratigráficas de topo e base, com associações litologicas similares, devendo corresponder a um mesmo episódio da evolução da bacia do Paraná, sendo portanto contemporâneas.

A espessura da Formação Rosário do Sul, equivalente ao Pirambóia, é bastante vàriável, aumentando sensivelmente de leste para oeste. Na área de Gravataí-Taquara a espessura é em torno de 120-150 m, enquanto na área-tipo deve ser superior a 300-400 m.

$\mathrm{Na}$ área-tipo, esta formação mantém o mesmo caráter cíclico da Formação Pirambóia em São Paulo. Cada ciclo corta clásticos finos do precedente, de modo que é muito freqüente a concentração de seixos de folhelhos na base dos ciclos (Gamermann, 1972).

2. Idade da Formação Pirambóia A determinação da idade de um pacote de sedimentos continentais é dificil por causa da carência de fósseis com valor cronológico. As ocorrências fossilíferas na Formação Pirambóia são localizadas e os fósseis descritos podem ter grande distribuição no tempo geológico. Os jazigos de Fartura e Serra de Santana, descobertos e estudados por Almeida (1950), apresentam uma fáunula de conchóstracos e ostracóides do Mesozóico.

Recentemente, Souza et al. (1971) descobriram novo jazigo na parte superior desta formação próximo à cidade de Serrana. Os fósseis crustáceos encontrados são também conchóstracos e ostracóides de água doce com gêneros dominantemente do Mesozóico. Encontram também o fóssil vegetal Lycopodiopsis derbyi. Este jazigo situa-se na parte superior do Pirambóia, próximo ao contato com o Botucatu (s.s.). É difícil conciliar as indicações de idade fornecidas por Lycopodiopsis, típico do Permiano, com o ostracóide Cypridea "sobremaneira freqüente" no limite juro-triássico, como dizem os autores.

A Formação Rio do Rasto, assentada sobre o Teresina no Estado do Paraná e com espessuras em torno de $200 \mathrm{~m}$, ausente no Estado de São Paulo por erosão, tem indicações paleontológicas de idade Permiana, o mesmo acontecendo com o próprio Teresina.

O ciclo de sedimentação pós-glacial, especialmente a Formação Tatuí (Soares, 1972b) e o Grupo Passa Dois, ocorreu no Permiano Superior (Kazaniano, segundo Daemon e Quadros, 1970), devendo ter se encerrado no final do Permiano, ou no início do Triássico com o membro Morro Pelado (Formação Rio do Rasto).

A superficie pré-Pirambóia foi peneplanizada, processo que deve ter envolvido largo intervalo do Triássico. Isto torna razoável supor que o início da fase de agradação esteja situado no Triássico Médio. A imprecisão da cronologia do início da deposição da Formação Pirambóia será, de qualquer forma, decorrente do próprio processo. Enquanto áreas. mais centrais já sofriam agradação, as áreas marginais se encontravam sob regime de degradação, de modo que as camadas basais desta formação são transgressivas no tempo.

Outro elemento fundamental na determinação da idade desta formação é sua correspondência com a Formação Rosário do Sul. As camadas Santa Maria constituem uma fácies da parte média a superior daquela unidade e contêm vertebrados fósseis cuja idade atribuída mais recentemente é Triássico Superior (Colbert, 1970; Bortoluzzi, 1974; Mendes, 1971). Desta forma, o limite superior da idade desta formação é estabelecido pela idade da Formação Serra Geral (limite Jurássico-Cretáceo; Cordani e Vandoros, 1967). Entreas duas ocorre a Formação Botucatu, cuja parte superior é contemporânea com o Serra Geral, como demonstraremos, e apresentando localmente espessura de poucas dezenas de metros.

Essas considerações permitem situar a época da deposição da Formação Pirambóia entre o Triássico Inferior e Jurássico Superior, mais provavelmente do Triássico Médio a Jurássico Inferior. 
b. FORMAÇÃ̃O BOTUCATU (stricto sensu) 1. Definição e ocorrência Usamos aqui Formação Botucatu para designar o pacote de arenitos de granulação fina e muito fina dominante, com estratificação cruzada de grande a médio porte, muito friáveis ou silicificados, apresentando na parte basal corpos de arenitos conglomeráticos e conglomerado. $\mathbf{E}$ admitida a existência de derrames basálticos nesta unidade. $\mathbf{O}$ pacote sedimentar desta formação constitui uma unidade genética depositada em ambiente desértico. A característica fundamental desta unidade é a monótona sucessão de corpos cuneiformes de arenitos com seleção regular a boa, com teor de lama (silte + argila) em média inferior a $10 \%$ (Tab. 2)

TABELA II - Valores médios de algumas propriedades texturais dos arenitos da Formação Bo* tucatu, por regiōes

\begin{tabular}{|c|c|c|c|c|c|}
\hline PARÂMETROS & $S P-N E$ & $S P-W L$ & $S P-C B-M R$ & $S P-S U L$ & PR \\
\hline $\begin{array}{c}\text { So } \text { (Selecão) } \\
\text { (Trask) }\end{array}$ & 0,77 & 0,74 & 0,70 & $(0,79)$ & $(0,59)$ \\
\hline $\begin{array}{c}\sigma^{\prime} \theta \text { (Desvio) } \\
\text { (Inman) }\end{array}$ & 0,53 & 0,85 & 0,72 & $(0,52)$ & $(1,05)$ \\
\hline $\begin{array}{c}a_{\emptyset} \\
(\text { Inman })\end{array}$ & 0,24 & 0,22 & 0,20 & $(0,18)$ & $(0,11)$ \\
\hline $\begin{array}{c}\text { Mz(tamanho médio } \\
\text { (Folk) }\end{array}$ & 2,25 & 2,75 & 2,56 & $(1,85)$ & $(1,68)$ \\
\hline $\begin{array}{c}\sigma 1 \text { (Desviapadrço) } \\
\text { (Folk) }\end{array}$ & 0,74 & 0,94 & 0,80 & $(0,75)$ & $(1,10)$ \\
\hline $\begin{array}{c}\% \text { lamo } \\
\text { (Silte + argila) }\end{array}$ & 7,4 & 8,25 & 9,53 & $(4,90)$ & $(9,34)$ \\
\hline
\end{tabular}

SP-NE: nordeste do Estado de Sc̃̃o Paulo (9 amostras)

SP-WL: centro-leste do Estado de Söo Paulo, rodovio Washington Luiz e proximidades (26 amostras)

S.P.-CB-MR: centro leste do Estado de São Paulo, rodovio Castelo Branco e Mare chal Rondon ( 16 a mostras)

S.P.SUL' regiäo sul do Estado de São Paulo (Fartura), (4 amostros)

PR: Paraná-BR-277-Serra da Esperanca (4 amostras)

Os corpos de arenitos conglomeráticos, com estratificação cruzada de porte médio a pequeno, têm ocorrência local. Apresentam pouca matriz e seixos facetados. São depósitos torrenciais realizados por correntes temporárias (ouadis). Mais rara é a ocorrência de depósitos lacustres, na parte superior da seção, constituídos de arenitos lamíticos e lamitos.

A designação Botucatu é tírada da Serra de Botucatu, Estado de São Paulo, e propomos manter aí sua seção-tipo, na Rodovia Marechal Rondon, entre os km 237,3 e 238. 
A espessura da Formação Botucatu é bastante variável, porém não ultrapassa $150 \mathrm{~m}$ em sua faixa de afloramentos no Estado de São Paulo. A espessura média é em torno de 50-70 m. Na seção-tipo apresenta $130 \mathrm{~m}$, espessura máxima medida. Sua ocorrência, de um modo geral, se restringe à parte inferior da escarpa da Serra Geral e está freqüentemente coberta por depósitos de tálus. Quando os arenitos são silicificados, ocorre em morros-testemunhos pouco afastados da frente da Serra. Mais raramente ocorre em faixas amplas apresentando-se coberta por extensos areais eluvionares ou coluviais, como na bacia do Jacaré-Guaçu.

A ocorrência de arenitos eólicos em todo o flanco leste e sul da Bacia do Paraná é tão conhecida que dispensaria referirmo-nos a tal tema. Entretanto as redefinições propostas e as interpretações ambientais exigem tal referência.

Embora com espessuras variáveis, a Formação Botucatu (s.s.) ocorre em toda a faixa de afloramentos do flanco leste e sul da bacia. As espessuras variam comumente entre 50 e $150 \mathrm{~m}$. Os maiores valores são encontrados em Santa Catarina e nordeste do Rio Grande do Sul. No Paraná, as espessuras estão em torno de 60 a $100 \mathrm{~m}$ similares às do Estado de São Paulo.

As características texturais das areias eólicas se mantêm uniformes em toda a faixa. A ocorrência de arenitos conglomeráticos de fácies torrencial no Paraná chega a atingir $8,5 \mathrm{~m}$ (Fig. 4). Nos Estados mais ao sul não vimos nem encontramos referências de depósitos que possam ser atribuídos às fácies lacustre e torrencial da formação. Entretanto, Gamermann et al. (1973) citam a existência de conglomerados, incluindo seixos de basalto, nesta unidade, no Rio Grande do Sul (Bom Retiro do Sul).

2. Idade da Formạ̧ão Botucatu A questão da idade da Formação Botucatu levanta imediatamente o problema da existência de arenitos interderrames.

$O$ fato de os basaltos da Formação Serra Geral terem idade conhecida através de datações geocronológicas é o ponto de referência fundamental. Segundo Cordani e Vandoros $(1967$, p. 217), a maioria das determinações radiométricas se situa entre 120 e 130 milhões de anos, e o intervalo da atividade vulcânica ter-se-ia estendido, pelos dados até então obtidos, entre 119 e 147 m.a. Tais idades correspondem ao Jurássico Superior e o Cretáceo Inferior.

Por muito tempo considerou-se como fora de dúvida a existência de espessos pacotes de arenito eólico sobrepostos aos primeiros derrames, tendo Cordani e Vandoros (op. cit.) admitido que "o íntimo relacionamento das rochas basálticas e as intercalações de arenito eólico indicam a perfeita contemporaneidade das duas litologias".

Entretanto, certos corpos de magmatitos básicos considerados como derrames, subjacentes ou intercalados na Formação Botucatu, na verdade têm apresentado caráter de rocha intrusiva (Melfi e Girardi, 1962; Fulfaro et al., 1967). As dificuldades de se estabelecer o caráter extrusivo ou intrusivo desses magmatitos, e portanto seu significado estratigráfico, são muitas. Revelações deste tipo criaram sérias dúvidas a respeito da existência de interdigitamento e penecontemporaneidade da Formação Botucatu com o Serra Geral, tendo Mendes (1971) levantado a questão: "Mas existiriam mesmo arenitos intratrapianos?" (p. 194)

São muitos os lugares em que são encontrados corpos de arenito eólico sobrepostos à zona vesicular ou amigdaloidal, de magmatitos, sem qualquer indicação de penetração do magma no arenito. Em muitos casos ocorre penetração do arenito no basalto sob a forma de dique.

$\mathrm{Na}$ Serra de Botucatu, uma seção de arenitos eólicos e basaltos muito conhecida apresenta feições bastante significativas (Fig. 3). Numa espessura de $115 \mathrm{~m}$ de arenitos eólicos 
ocorrem dois corpos de magmatito intercalados. Sobre o corpo inferior, na parte basal do arenito (ponto $63 \mathbf{J}$ ), ocorrem pequenos fragmentos de até $1,5 \mathrm{~cm}$ de basalto, altamente intemperizados. A presença de cristais de plagioclásio, textura de basalto, magnetita e/ou ilmenita, e pequenas vesículas nos fragmentos confirmam sua origem nos basaltos. Os fragmentos são angulosos, embora alguns apresentem certo arredondamento. Encontram-se numa camada de $5 \mathrm{~cm}$ de espessura de arenito.

No corpo superior de arenitos é́licos são encontradas bolas de até $30 \mathrm{~cm}$ de diâmetro de basalto vesicular, que foi interpretado por Washburne (1930) como piroclástico e por Mendes e Frakes (1964) como tálus fóssil. As duas interpretações indicam contemporaneidade com o vulcanismo. Nesta mesma área, Almeida (1953) encontrou material vulcânico (cinza, lapilli) intercalado nos arenitos eólicos.

Estas ocorrências não nos deixam dúvidas de que tal pacote de arenito é contemporâneo com a atividade vulcânica, tendo-se depositado, após o início deste fenômeno, $65 \mathrm{~m}$ de areia eólica. Este fato é suficientemente demonstrativo de que a sedimentação é́lica persistia à época do vulcanismo, tendo desaparecido, provavelmente, por recobrimento das dunas e também da área fonte mais próxima. Este fato é sugerido pelo caráter "transgressivo" dos derrames basálticos sobre a Formação Botucatu.

O limite superior da idade da Formação Botucatu coincide, pois, com o início da fase mais intensa do vulcanismo, provavelmente o limite Jurássico-Gretáceo. O limite inferior não pode ser estabelecido; deve, porém, estar situado no Jurássico.

c. FORMAÇÃ̃O SERRA GERAL A Formação Serra Geral constitui uma designação proposta por White em 1908 para o conjunto de basaltos formados por derrames em extenso vulcanismo de fissura. Inclui pequenos corpos de arenitos intercalados nos derrames. Mantém-se aqui este sentido para a Formação Serra Geral.

Dificuldades no contato basal desta unidade surgem nas diversas partes da Bacia do Paraná. Este problema já foi enfocado atrás, parecendo difícil uma definição segura para toda a bacia.

d. FORMAÇÃO BAURU Na região mapeada, e de um modo geral em toda a borda leste do planalto ocidental, a Formação Bauru é composta dominantemente por arenitos, raramente conglomeráticos, com estratificação cruzada de pequeno a médio porte, plano-paralela ou estrutura maciça. São arenitos imaturos, com bastante feldspato, mal selecionados, grãos subangulosos e subarredondados, com teor de matriz muito variável, cimento limonítico, calcário e silicoso. Ocorrências típicas destas rochas são encontradas no alto da Serra de Itaqueri e de Botucatu. A melhor exposição que encontramos foi em. Rubião Júnior, sudoeste de Botucatu, na área do mapa.

Para oeste e norte do Estado de São Paulo, a Formação Bauru pode ser dividida em dois pacotes, com base principalmente na intensidade de cimentação por calcário, conforme já observado por Setzer (1948) e Almeida e Barbosa (1953). O pacote inferior, cujas espessuras pouco ultrapassam $100 \mathrm{~m}$, é formado por arenitos vermelho-acastanhados, de granulação fina, com estratificação cruzada, mais raramente plano-paralela e maciça, abundante matriz silto-argilosa e cimento limonítico, friáveis. Raramente intercalam-se camadas de lamitos de mesma cor, arenosos.

O pacote superior se caracteriza pela presença de abundante cimento carbonático nos arenitos. Os arenitos apresentam acamamento plano-paralelo grosseiro ou camadas maciças, freqüentemente com concreções carbonáticas concentradas em níveis, assemelhando-se a conglomerado. Sua ocorrência restringe-se às serras nos divisores de água dos principais rios (Serra de Jabuticabal, de Agudos etc.). 
O pacote inferior apresenta características de depósitos fluviais de rios meandrantes, enquanto o superior lembra mais sedimentos fluviais de rios anastomosados, faltando depósitos de inundação.

Relaçóes de contato $\mathrm{O}$ caráter discordante entre o Pirambóia e as formaçðes mais antigas não pode ser posto em dúvida tantas são as evidências de que em toda a região as camadas permianas foram espostas à erosão no tempo pré-Pirambóia.

$\mathrm{Na}$ parte norte da área estudada, esta discordância é raramente visível dada a freqüência de falhas e intrusivas no contato. Em Piraçununga, nas cabeceiras do Riacho Laranja Azeda, a superficie de siltitos Estrada Nova encontra-se com estratificação cruzada tangenciando a superficie de erosão. Siltitos em contato direto com arenitos através de uma superficie ondulada é o tipo de contato mais comum da área de Corumbataí para norte. Em diversos locais, como na estrada de Anhembi para Conchas, à primeira vista há uma gradação da litologia do Estrada Nova para o Pirambóia. No primeiro, lamitos amarelados com intercalações de argila avermelhada e siltito passa a siltito arenoso aver. melhado, com finas lâminas de argila chocolate; o siltito torna-se mais arenoso a arenito muito fino, siltoso com estratificação plano-paralela: esta gradação ocorre num intervalo de $2 \mathrm{~m}$ e seria explicada pela presença de águas superficiais com baixa energia e baixo afluxo das areias.

A feição mais comum deste contato é, entretanto, um regolito fóssil, representada por uma brecha com matriz areno-argilosa sem estrutura aparente. Encontramo-la desde a Rodovia Washington Luis até a Serra da Fartura. Sua melhor exposição é na Rodovia Castelo Branco (km 166,5) (Fig. 5 e Foto 3). Os fragmentos são tabulares angulosos de tamanho inferior a $5 \mathrm{~cm}$, constituídos de siltitos de mesmas características que o sotoposto. Estes fragmentos são mais abundantes na base, onde, às vezes, se encontram ainda alguns não completamente soltos do substrato que é o Estrada Nova (Teresina). A matriz é areno-argilosa, vermelha, sem estrutura; este material, na base da brecha, preenche fraturas do siltito.

Em termos de afloramentos, em local algum percebemos evidências de discordância angular entre o Pirambóia e o Estrada Nova. Entretanto outros elementos nos mostram indicações de angularidade, embora pequena, nesta discordância.

A espessura média do intervalo entre um banco de sílex estromatolítico da Formação Estrada Nova e a discordância mostra um aumento gradativo para oeste, indicando haver truncamento das camadas da Formação Estrada Nova. As informações de campo são indicativas de que a superficie pré-Pirambóia foi aplainada, não apresentando à época do início da deposição do Pirambóia irregularidades maiores do que duas ou três dezenas de metros. $\mathrm{O}$ aplainamento pré-Pirambóia truncou camadas cada vez mais antigas do interior para os bordos da bacia: formaçóes Rio do Rastro, Estrada Nova e Aquidauana, indicando que há angularidade na superfície da discordância.

$O$ contato entre o membro inferior e o superior da Formação Pirambóia é muito mal definido litologicamente. No campo, ou na fotografia aérea, as características já descritas permitem separá-los, porém não existe uma superficie de contato com características definidas.

O contato entre as formações Botucatu e Pirambóia apresenta uma boa exposição numa estrada que sai de Charqueada para Serra de Itaqueri; na base da escarpa, o ravinamento junto à estrada expóe claramente a parte basal do Botucatu. As litologias e as estruturas sedimentares estão representadas na Fig. 6. Feição interessante é a ocorrência, sotoposta a sedimentos é́licos, de depósitos aquosos, com espessura de $2 \mathrm{~m}$ aproximadamente, com placas e bolas de argila, raros seixos, cuja gênese não sabemos se está ligada 


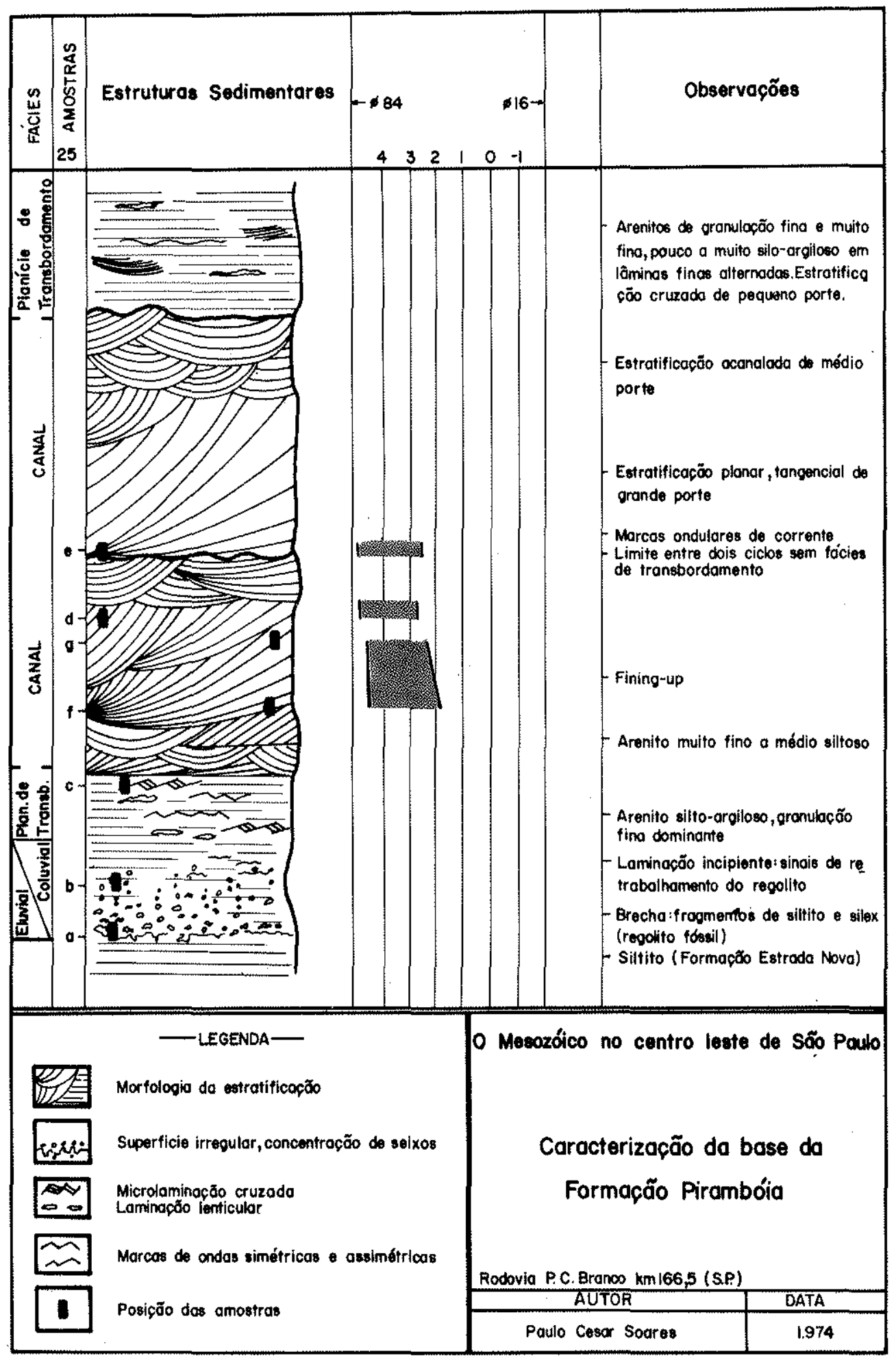

Figura 5 - Caracterização da base da Formação Pirambóia. Rodovia Castelo Branco, km 166,5 (SP) 


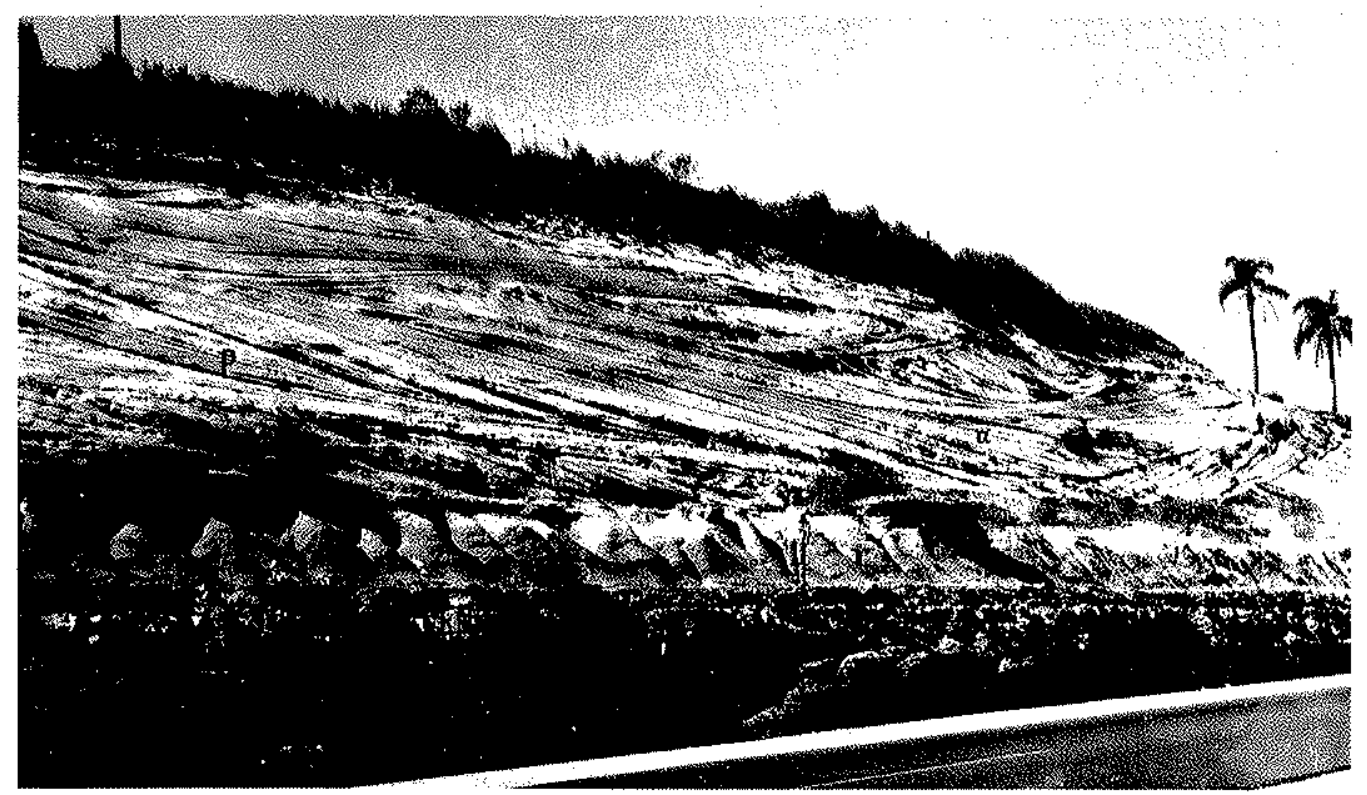

Foto 3 - Contato da Formação Pirambóia (P) com o Estrada Nova (EN). Depósitos de canal (a) sobre regolito fóssil (r) brechóide. Abaixo, lamitos e siltitos (Rodovia Gastelo Branco, SP, km 167)

ao ambiente fluvial ou a pequenos ouadis de ambiente desértico. Duas outras feições chamam a atenção do observador. A primeira, é a existência de uma camada de $2 \mathrm{~m}$ de arenito com laminação incipiente ou inexistente, entre os arenitos aquosos e os eólicos. Texturalmente, este arenito é similar ao eólico. É provável que esta camada seja o resultado da fossilização dos primeiros depósitos da areia trazida pelo vento. Estas areias teriam sido retidas num ambiente em que o lençol freático estava à superficie, impedindo a formação de lâminas rítmicas características das dunas. A outra feição é a presença de pequena concentração de grânulos, raros seixos, na superficie irregular do topo da camada maciça. Há também fraturas nesta superficie, preenchidas por material arenoso igual ao sobreposto. Notam-se também alguns blocos desta camada envoltos no arenito de cima. Os grânulos são interpretados como paleopavimento desértico numa área em que a disponibilidade de grosseiros era pequena. A camada eólica inicial foi ressecada, fraturada e retrabalhada pelo vento.

Em diversos locais, como na estrada Santa Maria da Serra para Torrinha; na Fazenda Ibitira, na Serra de Itatinga; no Morro Sarandi, pouco ao norte de Guaré, o topo da Formação Pirambóia é constitúdo por arenito muito fino a médio, laminação plano-paralela, contendo camadas de siltito e argila, fácies de planície de inundação; sobre estes sedimentos, assentam-se os arenitos eólicos, com estratificação cruzada, na base, tangenciando a superficie plana da formação inferior. Estes contatos refletem o avanço de duna sobre planícies aluviais do tempo Pirambóia.

Na Serra de Santana, na estrada da estação de Graúna para Itirapina, a base da Formação Botucatu apresenta um pacote de arenitos conglomeráticos, sem matriz, com camadas de arenito de granulação média, muito bem selecionado e ritmicamente laminado. Assenta-se sobre arenitos finos argilosos da Formação Pirambóia. Situação similar encontramos em outros locais fora da área desta pesquisa. Apresentaremos alguns detalhes deste tipo de contato, para mais bem caracterizá-lo, observados no Morro das Rosas, $5 \mathrm{~km}$ a 


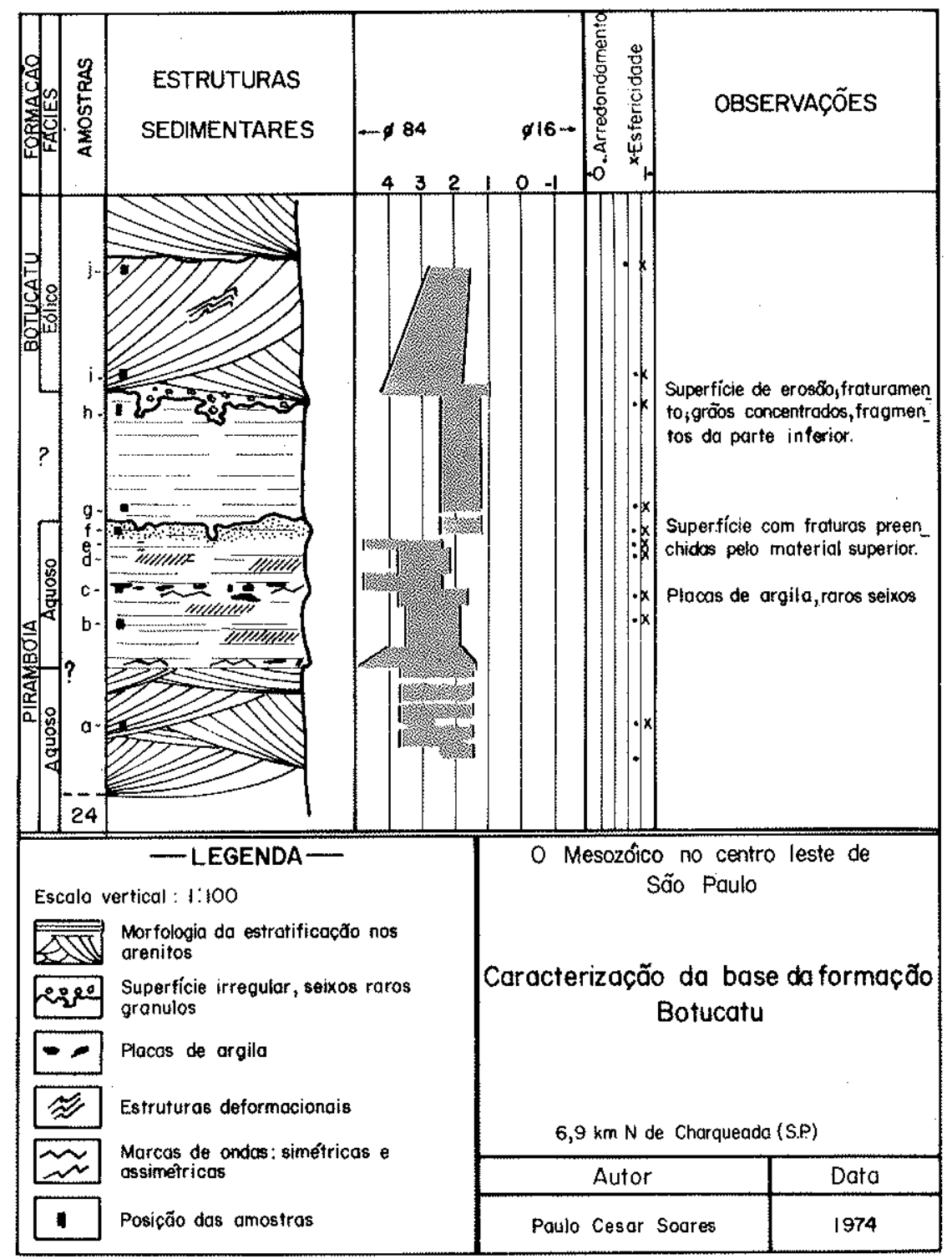

Figura 6 - Caracterização da base da Formação Botucatu, $6,9 \mathrm{~km}$ ao norte de Charqueadas (SP)

norte de Itirapuã (Foto 4). A parte basal do Botucatu é constituída de camadas de arenito conglomerático, com algumas camadas é́licas. O contato com o Pirambóia apresenta uma camada de 40 a $60 \mathrm{~cm}$ de espessura de seixos concentrados de tamanho variável até $30 \mathrm{~cm}$; são seixos de gnaisses, granitos, quartzitos, arenitos e lamitos arenosos vermelhos. Constitui um exemplo notável de reg ou pavimento desértico fóssil.

$\mathrm{Na}$ Rodovia Ponta Grossa-Foz do Iguaçu (BR-277), na Serra da Boa Esperança (PR), a parte basal do Botucatu é também torrencial, porém não encontramos o pavimento conglomerático fóssil. $\mathrm{O}$ contato aí é uma brusca mudança nas condições de sedimentação (Foto 2). 


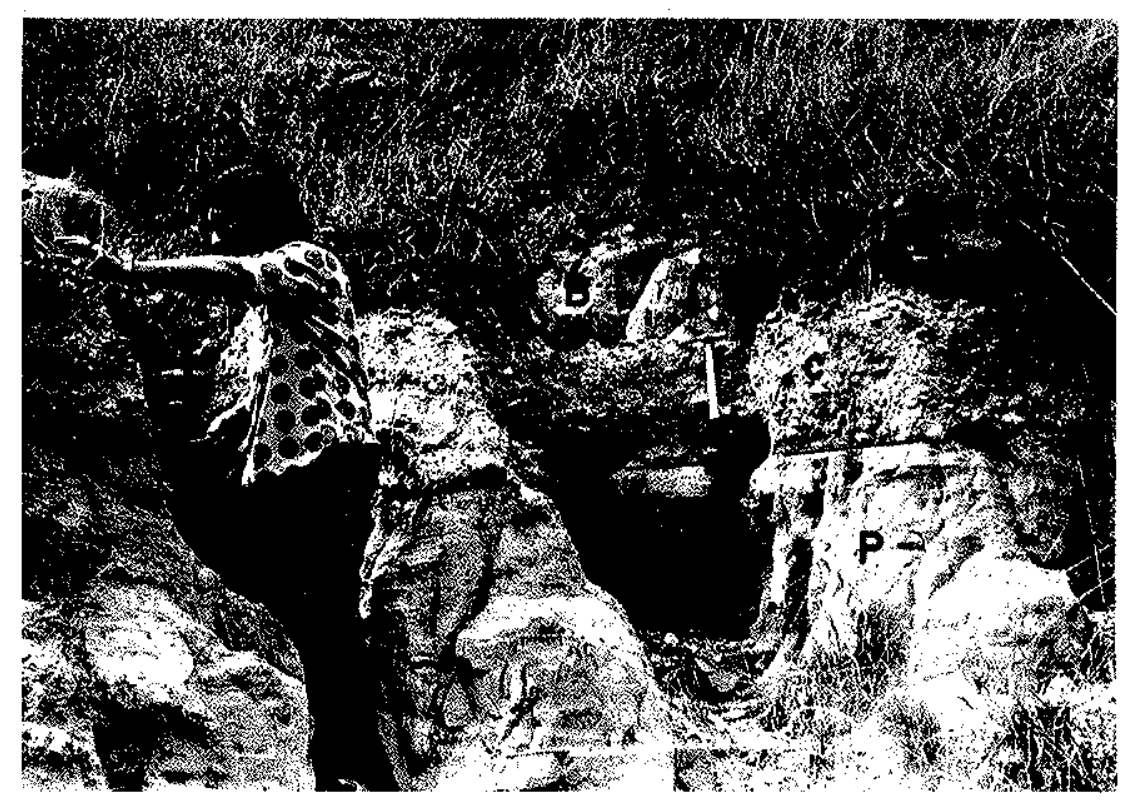

Foto 4 - Depósitos de arenito conglomerático da Formação Botucatu (B) em contato com arenitos do Pirambóia (P) através de uma camada de conglomerado (c) (Morro das Rosas, Itirapuã, SP)

As relações de contato entre as formações Botucatu e Pirambóia, embora revelem em muitos casos uma brusca mudança litológica c ambiental, uma descontinuidade na sedimentação, não significam necessariamente uma discordância. A existência de feições como concentração de seixos e superficie de contato retrabalhada é conseqüência natural da mudança ambiental de um regime fluvial para desértico.

CONCLUSÓES O Mesozóico da bacia do Paraná está representado por quatro ciclos maiores de acumulação. $\mathrm{O}$ ciclo mais antigo é constituído de depósitos fluviais, sendo sucedido por um ciclo de sedimentação dominantemente eólica, de ambiente desértico. O terceiro, um ciclo vulcânico, corresponde à espessa acumulação de lavas de composição basáltica. O Mesozóico encerrou-se com outro ciclo fluvial, sendo a última manifestação da dinâmica da bacia de sedimentação da Bacia do Paraná.

Estes quatro ciclos correspondem, respectivamente, às formações Pirambóia, Botucatu, Serra Geral e Bauru. A Formação Pirambóia, conforme é definida neste trabalho, constitui uma unidade fundamental na história geológica do Mesozbico. A espessura deste pacote, essencialmente de arenitos, ultrapassa $300 \mathrm{~m}$ na parte central do Estado de São Paulo, diminuindo gradativamente para o sul em direção ao Arco de Ponta Grossa e para nordeste rumo ao bordo da bacia. Na verdade, esta formação é constituída de vários ciclos fluviais representados por depósitos de canais sucedidos por depósitos de transbordamento. A uniformidade textural e mineralógica dos arenitos desta formação representa a intensidade do trabalho sofrido pelo material fornecido à bacia. Isso significa que tanto o suprimento quanto a subsidência foram muito lentos nestes ciclos maiores de sedimentação fluvial.

A Formação Botucatu, como aqui definida, restringe-se ao pacote de sedimentos de ambiente desértico. Está representada por três fácies: torrencial, lacustre e eólica, sendo esta a dominante. A torrencial é constituída de arenitos conglomeráticos depositados por 
wadis, sendo mais comum na parte basal da unidade. A lacustre constitui-se de lamitos arenosos, siltitos e arenitos lamíticos, ocorrendo mais freqüentemente na parte superior da formação ou já entre os primeiros derrames. Tal como a Formação Pirambóia, os arenitos da Formação Botucatu apresentam surpreendente homogeneidade textural e mineralógica, significando que a dinâmica da bacia permaneceu a mesma.

Em todo flanco leste e sul da Bacia do Paraná estas formações mantêm continuidade física, variando regionalmente de espessura, mas apresentando suas características muito similares. No Rio Grande do Sul, os sedimentos equivalentes ao Pirambóia são denominados Formação Rosário do Sul e englobam as camadas conhecidas como "Formação" Santa Maria.

A Formação Botucatu, na parte superior, encontra-se interdigitada com derrames basálticos da Formação Serra Geral. Derrames e fragmentos de basalto nos arenitos atestam a contemporaneidade da deposição eólica com o vulcanismo basáltico. Estes fatos permitem situar a deposição das formações Pirambóia e Botucatu entre o Triássico Inferior ou Médio e o limite Juro-Gretáceo.

O contato com a seqüência neopaleozóica é uma discordância erosiva, esculpida em grande parte na faixa aflorante sobre a Formação Estrada Nova. Gorresponde a um ciclo erosivo que peneplanizou a região, cortando diferentes unidades desde o Rio do Rasto até o embasamento cristalino.

Agradecimentos Registramos nossa especial gratidão ao Prof. Dr. Paulo M. B. Landim, aos geólogos Rodi A. Medeiros e Sebastião M. de Andrade, pelas discussões freqüentes que, certamente, conduziram a um aprimoramento de muitos conceitos envolvidos no trabalho. Agradecemos também ao Departamento de Exploração e Produção da Petróleo Brasileiro S.A. (Petrobrás), pela permissão de usarmos parte de nosso trabalho executado para esta empresa e consultarmos outros relatórios e perfis de poços.

\section{BIBLIOGRAFIA}

ALMEIDA, F.F.M. de - 1950 - Uma fáunula de crustáceos bivalves do Arenito Botucatu no Estado de São Paulo, Brasil. D.G.M. - D.N.P.M., Bol. 134, 34 pp.

ALMEIDA, F. F. M. de - 1953 - Botucatu, a triassic desert of South America. 19. ${ }^{\circ}$ Congr. Geol. Inter., Alger, 1952. Compte Rendus, Sec. VII, fasc. VII, 9-24

ALMEIDA, F.F.M. de e BARBOSA, O. - 1953 - Geologia das quadrículas de Piracicaba e Rio Claro, Estado de São Paulo, Brasil. D.N.P.M. - D.G.M., Bol. 143, 96 pp.

ANDRADE, S. M. e SOARES, P. C. - 1971 - Geologia do Centro-Leste do Estado de São Paulo: PETROBRÁS-DESUL, Rel. 407 (inédito), Ponta Grossa

BORTOLUZZI, G. A. - 1974 - Contribuição à Geologia de Santa Maria, Rio Grande do Sul, Brasil. Pesquisas 4: 1-86, Porto Alegre

BÓSIO, N. J. e LANDIM, P. M. B. - 1971 - Um estudo sedimentológico sobre a Formação Caiuá. Bol. Paran. Geoc, 28/29: 145-157

COLBERT, E. H. - 1970 - A saurischian Dinosaur from the Triassic of Brazil. An. Mus. Novitates, 2405: 1-39

CORDANI, U. G. e VANDOROS, P. - 1967 - Basaltic rocks of the Paraná Basin. In: "Problems in Brazilian Gondwana Geology", 207-231, Curitiba

DAEMON, R.F. e QUADROS, L. P. - 1970 - Bioestratigrafia do Neopaleoź́ico da Bacia do Paraná, XXIV Congr. Bras. Geol., Soc. Bras. Geol., Brasilia. Anais, 359-412

FIGUEIREDO F. ${ }^{\circ}$, P. M. - 1972 - A faciologia do Grupo Passa Dois no Rio Grande do Sul. S.B.G., Rev. Bras. Geol., 2(4): 216-235

FULFARO, V.J. e BOSIO, N. J. - 1968 - Novas observações sobre a faciologia do Arenito Botucatu no Estado de São Paulo. XXII Congr. Bras. Geol., Res., 57-59 
FUlfARO, V.J., LANDIM, P. M. B. e ELLERT, N. - 1967 - A Tectônica das Serras de Santana e São Pedro (Serra Geral). An. XXI Congr. Bras. Geol., 198-205

GAMERMANN, N. - 1972 - Formação Rosário do Sul. U.F.R.G.S., Inst. Geoc., Pesquisas, 2, 5-36

GAMERMANN, N., COULON, F. K., CARRARO, G. G. e ELCK, N. - 1973 - Conglomerado Bom Retiro do Sul. XXVII Congr. Bras. Geol., Res. Bol. 1: 146-14.7

HARMS, J. C. e FAHNESTOCK, R. K. - I965 - Stratification, bedforms, and flow phenomena (with an example from the Rio Grande). In Primary Sedimentary Structures and Their Hydrodynamic Interpretation. S.E.P.M. Spec. Publ., 12: 84-114

LANDIM, P. M. B. e FULFARO, V. J. - 1972 - Nota sobre a gênese da Formação Caiuá. S.B.G., XXV Congr. Bras. Geol., Anais, 2: 277-280

MELFI, A. J. e GIRARDI, V. A. V. - 1962 - Ocorrência de um sill de diabásio no Arenito Botucatu, Município de Igarapava, SP. Soc. Bras. Geol., 11 (2): 55-70

MENDES, J. C. - 196I - Algumas considerações sobre a estratigrafia da Bacia do Paraná. Bol. Paran. Geogr., 4/5: 3-33

MENDES, J. G. - 1971 - As camadas gonduânicas do Brasil e seus problemas. An. Acad. Bras. Cien., 43: $187-196$

MENDES, J. C. e FRAKES, L. - 1964 - Tálus fóssil na Formação Botucatu. Bol. da Soc. Bras. Geol., 13 (1 e 2): 67

MENDES, J. C. e FULFARO, V. J. - 1968 - Nova interpretação da tectônica moderna da Bacia do Paraná. Res. Giên. e Cult., 20 (2): 155

PARAGUASSU, A. B. - 1968 - Contribuição ao estudo da Formação Botucatu: Sedimentitos aquosos, estruturas sedimentares e silicificação. Tese de doutoramento, Esc. Eng. São Carlos, USP (inédito)

SALAMUNI, R. e BIGARELLA, J. J. - 1967 - The Botucatu Formation. In: "Problems in Brazilian Gondwana Geology", Univ. Fed. Paraná, Curitiba. 197-206

SANFORD, R. M. e LANGE, F. W. - 1960 - Basin study approach for oil evaluation of Paraná miogeosyncline of South Brazil. Bull. Amer. Assoc. Petrol. Geol., 44 (8): 1316-1 370

SETZER, J. - 1948 - Algumas contribuiçðes geológicas dos estudos de solos realizados no Estado de São Paulo. Rev. Bras. Geogr., Rio de Janeiro, 6, Série A

SOARES, P. C. - 1972a - Arenitos Botucatu e Pirambóia no Estado de São Paulo. XXVl Congr. Bras. Geol., Bol. 1, 250-251

SOARES, P. C. - 1972b - O limite glacial-pós-glacial do Grupo Tubarão no Estado de São Paulo. An. Acad. Brasil. Ciên., 44 (Suplem.)

SOARES, P. C. - 1973 - O Mesozbico Gonduânico no Estado de São Paulo. Tese de doutoramento. Fac. Fil. Gi. Let. de Rio Claro, SP (inédito)

SOARES, P. C., Sinelli, O., PENALVA, F., WERniGK, E., SOUZA, A. e CASTRO, P. R. M. - 1973 - Geologia do Nordeste do Estado de São Paulo. XXVII Congr. Bras. Geol. Aracaju (no prelo)

SOUZA, A., SINELLI, O. e GONĢALVES, N. M. M. - 1971 - Nova ocorrência fossilífera na Formação Botucatu. XXV Congr. Bras. Geol. Anais, 2: 281-295

WASHBURNE, C. W. - 1930 - Petroleum geology of State of São Paulo. Com. Geog, Geol. São Paulo, Bol. 22

WASHbURNE, C. W. - 1936 - Geologia do petróleo no Estado de São Paulo. Com. Geog. e Geol., São Paulo. Trad. e notas de J. Pacheco

WHITE, I. D. - 1908 - Relatório final da Comissão de Estudos das Minas de Carvão de Pedra do Brasil. Imprensa Nacional, Rio de Janeiro 